\title{
ABSORPSI AIR KOMPOSIT SEMEN SEKAM PADI DENGAN PENAMBAHAN POZZOLAN ABU SEKAM PADI DAN KAPUR PADA MATRIKS SEMEN
}

\author{
Water Absorption of rice Husk-Cement Composite by Adding Rice Husk Ash and Lime \\ to the Cement Matrix
}

Bakri dan Baharuddin

\begin{abstract}
This research aimed to determine the role of rice husk ash as pozzolanic material in reducing water absorption of rice husk cement composite. Rice husk ash obtained by burning rice husk conventionally in kiln drum. Preparation of water absorption testing samples was conducted according to ASTM C 140, while ASTM C 90 used to evaluate the desired water absorption. Rice husk ash as of $40 \%$ significantly reduced water absorption of the composite, but only rice husk ash of $20 \%$ dan $30 \%$ fulfilled the ASTM C 90 requirement. Addition of lime in the mixture increased the water absorption.
\end{abstract}

Key words: pozzolamic, water absorption, rick husk, rice husk ash.

\section{PENDAHULUAN}

Keberhasilan penggunaan kayu untuk menghasilkan komposit semen baik berbentuk panel maupun blok memacu penggunaan bahan lignosellulosa alami lainnya terutama yang berasal dari tanaman pertanian untuk membuat produk sejenis. Bahan-bahan berligno-sellulosa umumnya dapat dimanfaatkan sebagai bahan baku pembuatan komposit baik yang menggunakan matriks polimer sintetis seperti resin thermosetting maupun matriks keramik seperti semen.

Serat alami dari tanaman pertanian seperti serat batang tanaman sereal (batang jagung), serat dari phloem (jute, kenaft, flax, dan hemp), serat dari daun (sisal dan nenas), serat dalam buah dan kulit buah (kapas, sabuk kelapa, dan sekam padi), dan rumput (rumput gajah) merupakan bahan potensil untuk menghasilkan material komposit .

Serat alami selama ini paling banyak digunakan sebagai bahan komposit yang menggunakan matriks polimer baik sintetis maupun alami. Produk komposit serat alami yang menggunakan matriks polimer sintetis thermoplastic yang cukup berkembang di Amerika Serikat saat ini adalah wood/natural fiber-plastic composites (WPCs). Selain itu penggunaan perekat atau matriks keramik atau anorganik untuk serat alami juga mulai dikembangkan di berbagai negara termasuk penggunaan serat alami sekam padi. Beton ringan mungkin dapat dibuat dari sekam padi karena sifat serat sekam padi pada campuran beton dapat mengurangi kerapatan beton (Jauberthie et al., 2000).

Sekam padi merupakan bahan berlignosellulosa seperti biomassa lainnya namun mengandung silika yang tinggi. Silika sekam padi dalam bentuk kristalin (quartz dan opal) dan amorf terkonsentrasi pada bagian permukaan luar dan sedikit pada bagian dalam sekam (Jauberthie et al., 2000). Kandungan kimia sekam padi terdiri atas $50 \%$ sellulosa, $25-30 \%$ lignin, dan $15-20 \%$ silika (Ismail and Waliuddin, 1996). Porositas sekam padi yang sangat tinggi yaitu sekitar $79 \%$ menyebabkan sekam padi dapat menyerap air dalam jumlah yang banyak (Kaboosi, 2007). Namun demikian karena mengandung lignin dan silika yang cukup tinggi menyebabkan sekam padi sulit terdekomposisi oleh air dan jamur perusak dan pembusuk sehingga cocok digunakan sebagai agregat komposit semen.

Masalah yang mungkin terjadi dalam pemanfaatan sekam padi untuk pembuatan komposit yang menggunakan matriks keramik (semen) yaitu besarnya nilai absorpsi air yang terjadi. Untuk mengatasi penyerapan air dalam jumlah yang banyak pada komposit semen maka volume dan ukuran rongga komposit semen harus dikurangi. Pengurangan volume dan ukuran rongga komposit semen dapat dilakukan dengan menambahkan bahan pozzolan pada matriks semen yang digunakan. Bahan pozzolan ini jika bercampur dengan semen dan air akan menghasilkan kalsium silikat hidrat (CSH) sekunder setelah proses hidrasi berlangsung. $\mathrm{CSH}$ sekunder ini akan mengurangi 
bahkan menutup rongga yang terbentuk pada komposit semen sehingga akan mengurangi permeabilitas air yang akan masuk ke agregat sekam padi.

Pasta semen setelah proses hidrasi selalu mengandung rongga-rongga berupa makropori, pori kapiler, dan pori gel dengan ukuran yang bervariasi. Rongga-rongga ini menempati $5-6 \%$ volume pasta semen yang telah terhidrasi. Pori gel merupakan lapisan antar ruang $\mathrm{CSH}$ yang memiliki jarak antara $1 \mathrm{~nm}$ sampai beberapa nm. Pori kapiler merupakan rongga-rongga yang tidak terisi oleh senyawa hasil hidrasi yang memiliki diameter 10 sampai $50 \mathrm{~nm}$ pada pasta semen yang memiliki rasio air/semen rendah.

Pori kapiler tidak akan terbentuk jika air yang menempati ruang-ruang digantikan oleh senyawa hasil hidrasi selama proses hidrasi terjadi. Ketika proses hidrasi terjadi ruang-ruang yang diisi oleh air pada pasta semen akan ditempati oleh senyawasenyawa hasil hidrasi terutama CSH yang akan mengurangi permeabilitas dan meningkatkan kekuatan pasta semen (Thomas et al., 2008). Makropori terjadi dalam betuk gelembung udara ketika pecampuran pasta semen dilakukan yang memiliki diameter antara 0,05 sampai 0,2 mm.

$\mathrm{Hu}$ and Stroeven (2005) mengemukakan bahwa pengetahuan mengenai struktur pori secara rinci diperlukan untuk memahami sifat-sifat kekuatan dan ketahanan komposit semen namun hingga saat ini karakteristik struktur pori secara kuantitatif masih merupakan tantangan karena kerumitan jaringan interkoneksitas pori dalam pasta semen. Pengaruh bahan tambahan seperti pozzolan terhadap terbentuknya struktur mikro hasil hidrasi pada pasta semen juga belum banyak diketahui (Peterson et al., 2006). Bentz (2007) menganalogkan hidrasi semen dalam konstruksi skala besar sebagai jembatan bangunan yang menghubungkan partikel-partikel semen dan sebagai bendungan yang memutuskan hubungan ruang pori kapiler yang terisi air. Ketika jembatan mikro struktur merupakan kondisi kritis dalam pengembangan sifat-sifat mekanis maka bendungan mikro struktur membatasi pengangkutan dan meningkatkan ketahanan semen. Ketika hidrasi semen menghubungkan partikel-partikel semen secara bersama-sama maka hidrasi semen juga memutuskan porositas kapiler yang terisi air.

Manfaat sekam padi saat ini telah dikembangkan pula sebagai bahan baku untuk menghasilkan abu pozzolan yang dikenal di dunia sebagai abu sekam padi (rice husk ask). Abu sekam padi yang dihasilkan dari pembakaran sekam padi pada suhu $400^{\circ}$ - 500 C akan menjadi silika amorphous dan pada suhu lebih besar dari $1000^{\circ} \mathrm{C}$ akan menjadi silika kristalin (Shinohara and Kohyama, 2004). Kandungan silika pada abu sekam padi berkisar antara 92 - $95 \%$, sangat porous dan ringan, dan memiliki luas permukaan yang sangat besar (DTI, 2003). Muthadhi et al. (2007) mengemukakan bahwa abu sekam padi memiliki aktivitas pozzolanic yang sangat tinggi sehingga lebih unggul dari Supplementing cementitious material (SCM) lainnya seperti fly ash, slag, dan silica fume.

Penggunaan abu sekam padi dengan kombinasi campuran yang sesuai pada semen akan menghasilkan komposit semen yang lebih baik (Singh et al., 2002). Abu sekam padi telah digunakan sebagai bahan pozzolan reaktif yang sangat tinggi untuk meningkatkan mikrostruktur pada daerah transisi interfase antara pasta semen dan agregat. Walaupun Sarawathy and Song (2007) menyarankan penggunaan abu sekam padi sebesar $25 \%$ untuk membuat komposit semen tetapi penggunaan abu sekam padi sampai $30 \%$ sebagai pengganti sebagian semen masih dapat mengurangi penetrasi klorida, mengurangi permeabilitas, meningkatkan kekuatan, dan meningkatkan sifat anti karat komposit semen. Abu sekam padi telah digunakan sebagai SCM dalam pembuatan beton yang memiliki kekuatan tinggi dan permeabilitas rendah pada jembatan, bangunan dermaga, dan bangunan pembangkit tenaga nuklir karena abu sekam padi dapat meningkatkan reaksi pozzolan untuk pembentukan kalsium silikat hidrat (Dakroury and Gasser, 2008).

\section{BAHAN DAN METODE}

Bahan penelitian terdiri atas semen Portland tipe I, kapur, sekam padi, dan air destilasi yang tersedia di Makassar. Abu pozzolan sekam padi dibuat seperti yang dilakukan oleh Harsono (2002) dan Ganesan et al. (2008). Instrumen penelitian terdiri atas gelas ukur, timbangan digital, thermometer, hygrometer caliper, molder kubus $50 \mathrm{x}$ $50 \times 50 \mathrm{~mm}$, baskom, ember, kantung plastik, dandang aluminium, drum ayakan, mixer, tanur, dan komputer. Penelitian dilaksanakan pada Januari sampai Mei 2010 di laboratorium Pemanfaatan dan Pengolahan Hasil Hutan Universitas Hasanuddin.

Penelitian yang dilaksanakan merupakan penelitian eksperimental yang menggunakan percobaan faktorial. Rancangan dasar yang 
digunakan dalam percobaan faktorial adalah rancangan acak lengkap (RAL). Rancangan acak lengkap ini terdiri atas 3 faktor sebagai variabel bebas yaitu faktor abu sekam padi (A) yaitu persentase berat abu sekam padi terhadap berat matriks (Semen + Kapur + abu sekam padi), faktor sekam padi $(B)$ yaitu persentase berat sekam padi terhadap berat matriks (Semen + Kapur + Abu Sekam Padi), dan faktor persentase perbandingan semen dan kapur $(C)$ yaitu rasio berat semen dan kapur terhadap berat (Semen + Kapur). Faktor A terdiri atas 4 taraf yaitu $0 \%(\mathrm{~A} 0), 20 \%(\mathrm{~A} 1), 30 \%$ (A2), dan $40 \%$ (A3), faktor $B$ terdiri atas 2 taraf yaitu $30 \%$ (B1) dan $40 \%$ (B2), dan faktor $\mathrm{C}$ terdiri atas 3 taraf yaitu $100: 0$ (C1), $75: 25(\mathrm{C} 2)$, dan $50: 50$ (C3).

Prosedur pembuatan dan pengujian contoh uji absorpsi air merujuk pada ASTM C 140 dengan berbagai penyesuaian seperti ukuran contoh uji dan pelaksanaan curing. Sedangkan indikator nilai absorpsi air dievaluasi dengan menggunakan kriteria ASTM C 90. Pembuatan contoh uji dilakukan dengan cara memasukkan masing-masing campuran berdasarkan kombinasi percobaan ke dalam molder kubus yang memiliki ukuran $50 \times 50 \mathrm{x}$ $50 \mathrm{~mm}$. Jumlah ulangan pada setiap kombinasi campuran adalah 3 buah. Campuran yang telah dimasukkan ke dalam molder disimpan selama 1 hari kemudian dikeluarkan dari molder dan disimpan pada suhu ruangan selama 7 hari curing period. Contoh uji dicelup selama 24 jam dan setelah itu ditimbang dalam keadaan tergantung untuk mendapatkan berat contoh uji dalam air (Wi). Contoh uji dikeluarkan dari air kemudian dibiarkan selama 1 menit dan permukaannnya dilap. Contoh uji kemudian ditimbang untuk mendapatkan berat contoh uji jenuh air (Ws). Contoh uji kemudian disimpan pada suhu $24^{\circ} \mathrm{C}$ selama 21 hari curing period lanjutan. Contoh uji ditimbang setelah 21 hari curing period lanjutan sebagai berat contoh uji kering udara (We). Contoh uji kemudian dimasukkan ke dalam tanur pada suhu $100^{\circ} \mathrm{C}-115^{\circ} \mathrm{C}$ selama 24 jam. Contoh uji dikeluarkan dari dalam tanur kemudian ditimbang untuk mendapatkan berat contoh uji kering tanur (Wd). Absorpsi dihitung berdasarkan rumus $\mathrm{A}\left(\mathrm{kg} / \mathrm{m}^{3}\right)=\{(\mathrm{Ws}-\mathrm{Wd}) /(\mathrm{Ws}-$ Wi)\} $\times 1000$.

\section{HASIL DAN PEMBAHASAN}

Hasil perhitungan nilai absorpsi air contoh uji rata-rata dapat dilihat pada Lampiran 1. Nilai absorpsi air contoh uji rata-rata pada Lampiran 1 berkisar antara $275,1 \mathrm{~kg} / \mathrm{m}^{3}$ pada komposisi campuran A1B1C1 $\{(20: 30:(100: 0)\}$ sampai dengan $363,8 \mathrm{~kg} / \mathrm{m}^{3}$ pada komposisi campuran A3B2C3\{(40:40: (50:50)\}. Berdasarkan persyaratan nilai absorpsi air maka hanya perlakuan komposisi campuran $\mathrm{A} 1 \mathrm{~B} 1 \mathrm{C} 1$ dan $\mathrm{A} 2 \mathrm{~B} 1 \mathrm{C} 1$ yang memenuhi syarat ASTM C 90.

Hasil analisis keragaman menunjukkan bahwa masing-masing perlakuan pada faktor $\mathrm{A}$ (persentase abu sekam padi), $B$ (persentase sekam padi), dan $C$ (perbandingan semen dan kapur) berpengaruh nyata terhadap absorpsi air contoh uji. Sedangkan interaksi antar faktor perlakuan menunjukkan pengaruh yang tidak nyata terhadap absorpsi air. Untuk mengetahui perbedaan pengaruh masingmasing faktor $\mathrm{A}, \mathrm{B}$, dan $\mathrm{C}$ maka dilakukan uji lanjut BNJ dengan menggunakan prosedur Tukey yang hasilnya dapat dilihat pada Tabel 1, 2, dan 3 .

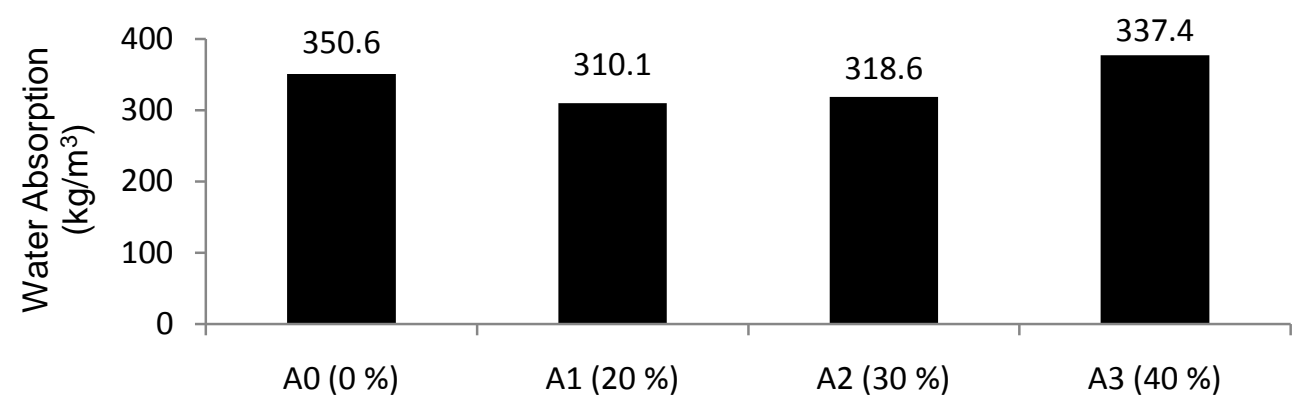

Rice Husk Ask Percentage (\%)

Figure 1. Main effect of rice husk ask percentage to the wateraAbsorption 
Nilai absorpsi air contoh uji rata-rata sebaga akibat dari pengaruh faktor A pada berbagai persentase abu sekam padi dapat dilihat pada Histogram 1. Histogram 1 menunjukkan nilai absorpsi air contoh uji rata-rata karena pengaruh faktor A (persentase abu sekam padi) masingmasing adalah $350,6,337,4,318,6$, dan $310,1 \mathrm{~kg} / \mathrm{m}^{3}$ yang terjadi pada persentase abu sekam padi $\mathrm{AO}(0$ $\%)$, A3 (40\%), A2 (30\%), dan A1 (20\%).

Histogram 1 menunjukkan pula bahwa absorpsi air contoh uji pada semua komposisi campuran yang menggunakan abu sekam padi yaitu A3 (40\%), A2 $(30 \%)$, dan A1 (20\%) memiliki nilai yang lebih kecil dari komposisi campuran yang tidak menggunakan abu sekam padi ( $0 \%)$. Hal ini membuktikan bahwa penggunaan abu sekam padi dapat menurunkan nilai absorpsi air contoh uji dengan nilai terendah yaitu $310,1 \mathrm{~kg} / \mathrm{m}^{3}$ terjadi pada penambahan persentase $20 \%$ (A1).

Hasil uji BNJ pada Tabel 1 mengenai pengaruh faktor A (persentase abu sekam padi) terhadap absorpsi air menunjukkan bahwa nilai absorpsi air contoh uji rata rata terendah sebesar $310,1 \mathrm{~kg} / \mathrm{m}^{3}$ terjadi pada perlakuan persentase abu sekam padi $20 \%$ dan nilai absorpsi air contoh uji rata rata tertinggi sebesar $350,6 \mathrm{~kg} / \mathrm{m}^{3}$ terjadi pada perlakuan persentase abu sekam padi $0 \%$. Tabel 1 menunjukkan pula bahwa perlakuan persentase abu sekam padi $20 \%$ dan $30 \%$ berbeda nyata dengan perlakuan persentase abu sekam padi $0 \%$ dan 40 $\%$ dan perlakuan persentase abu sekam padi $40 \%$ berbeda nyata dengan perlakuan persentase abu sekam padi $0 \%$.

Table 1. Tukey's HSD test of main effect $A$ (rice husk ash percentage) to the water absorption $\left(\mathrm{kg} / \mathrm{m}^{3}\right)$

\begin{tabular}{|c|c|c|}
\hline $\mathrm{A}(\%)$ & $\begin{array}{c}\text { Average Water } \\
\text { Absorption }\left(\mathrm{kg} / \mathrm{m}^{3}\right)\end{array}$ & BNJ $0,05=10,13$ \\
\hline 20 & 310,1 & a \\
\hline 30 & 318,6 & a \\
\hline 40 & 337,4 & $b$ \\
\hline 0 & 350,6 & C \\
\hline nark: & $\begin{array}{l}\text { same letter in } \\
\text { difference }\end{array}$ & te no sic \\
\hline
\end{tabular}

Perbedaan nilai absorpsi air contoh uji karena pengaruh faktor $A$ (persentase abu sekam padi) berhubungan dengan jumlah air yang diserap oleh contoh uji. Jumlah air yang diserap tergantung pada volume rongga contoh uji yang dapat diisi oleh air sedangkan volume rongga yang dapat diisi oleh air dapat diketahui dari nilai porositas contoh uji.
Semakin tinggi nilai porositas maka semakin besar volume rongga yang dapat diisi oleh air.

Nilai porositas contoh uji yang disebabkan oleh faktor abu sekam padi pada A0 (0\%) lebih besar dari A2 (20\%), A3 (30\%), dan A4 (40\%). Dengan demikian volume rongga contoh uji yang disebabkan oleh faktor abu sekam padi pada A0 (0\%) lebih besar dari A2 (20\%), A3 (30\%), dan A4 (40\%). Perbedaan volume rongga ini disebabkan oleh karena abu sekam padi memiliki peran untuk mengurangi ukuran rongga-rongga pori. Semakin banyak CSH yang dihasilkan oleh reaksi abu sekam padi dengan $\mathrm{CH}$ maka semakin banyak pori yang memiliki ukuran lebih kecil sehingga daya tampung pori terhadap air semakin berkurang. Jumlah air yang semakin berkurang pada contoh uji menghasilkan nilai absorpsi yang semakin rendah.

Nilai absorpsi air yang kecil akibat penambahan abu sekam padi pada semen dapat terjadi karena semakin berkurangnya air yang dapat ditampung oleh contoh uji. Semakin berkurangnya air yang dapat ditampung terjadi karena 2 faktor yaitu (1) semakin kecilnya rongga pori atau semakin kecilnya ruang zona interfasial dan (2) tertutupnya interkoneksitas antara rongga-rongga pori dan zona interfasial sehingga terjadi deperkolasi yang memutuskan hubungan antara pori dan zona interfasial. Rongga pori dan zona interfasial menjadi lebih kecil karena pembentukan CSH sekunder di permukaan bagian dalam pori dan zona interfasial. Jika rongga pori yang sangat kecil dipenuhi oleh $\mathrm{CSH}$ sekunder maka pori ini akan tertutup dan memutuskan hubungan transportasi air antar pori. Semakin banyak pori yang tidak memiliki interkoneksitas maka semakin sedikit air yang dapat diserap oleh contoh uji. Air yang terjebak dalam rongga pori yang tidak memiliki interkoneksitas dengan pori lainnya tidak akan melakukan pergerakan dalam contoh uji dan tidak diperhitungkan sebagai air yang diserap. Air yang dihitung sebagai air yang diserap dalam contoh uji adalah air yang dapat bergerak ke dalam dan ke keluar contoh uji melalui pori yang saling terhubung.

Nilai absorpsi air contoh uji rata-rata sebagai akibat dari pengaruh faktor $\mathrm{B}$ pada berbagai taraf persentase sekam padi dapat dilihat pada Histogram 2. Histogram 2 menunjukkan nilai absorpsi air contoh uji rata-rata karena pengaruh faktor B (persentase sekam padi) masing-masing adalah 317,0 dan $341,4 \mathrm{~kg} / \mathrm{m}^{3}$ yang terjadi pada persentase sekam padi B1 (30\%) dan B2 (40\%). 


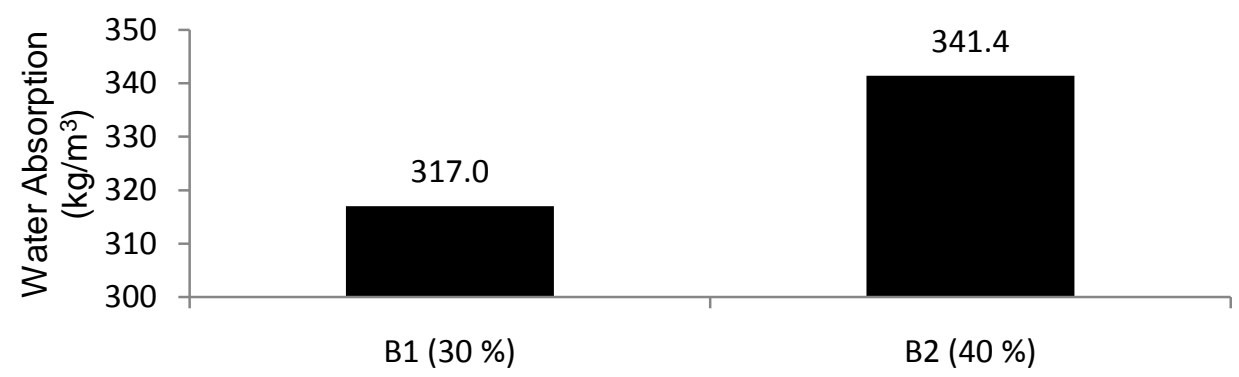

Rice Husk Percentage (\%)

Figure 2. Main effect of rice husk percentage to the water absorption

Hasil uji BNJ pada Tabel 2 mengenai pengaruh faktor B (persentase sekam padi) terhadap absorpsi air menunjukkan bahwa nilai absorpsi air contoh uji rata rata terendah sebesar $317,0 \mathrm{~kg} / \mathrm{m}^{3}$ terjadi pada perlakuan persentase sekam padi $30 \%$ dan nilai absorpsi air contoh uji rata rata tertinggi sebesar $341,4 \mathrm{~kg} / \mathrm{m}^{3}$ terjadi pada perlakuan persentase sekam padi $40 \%$. Tabel 2 menunjukkan pula bahwa perlakuan persentase sekam padi $40 \%$ berbeda nyata dengan perlakuan persentase sekam padi $30 \%$.

Table 2.Tukey's HSD test of main effect $B$ (rice husk percentage) to the water absorption $\left(\mathrm{kg} / \mathrm{m}^{3}\right)$

\begin{tabular}{|c|c|c|}
\hline B (\%) & $\begin{array}{c}\text { Average Water } \\
\text { Absorption } \\
\left(\mathrm{kg} / \mathrm{m}^{3}\right)\end{array}$ & BNJ 0,05 = 2,42 \\
\hline 30 & 317,0 & $\mathrm{a}$ \\
40 & 341,4 & $\mathrm{~b}$ \\
\hline Remark: & $\begin{array}{l}\text { same letter indicate no significant } \\
\text { difference }\end{array}$
\end{tabular}

Perbedaan nilai absorpsi air contoh uji karena pengaruh faktor $B$ (persentase sekam padi) disebabkan oleh jumlah air yang dapat diserap oleh contoh uji. Jumlah air yang dapat diserap oleh sekam padi tergantung pada kemampuan sekam padi untuk menyerap air dan kemampuan air menembus rongga pori contoh uji sampai ke permukaan agregat sekam padi.

Air yang dapat diserap oleh sekam padi mulai terjadi pada saat pencampuran semua bahan contoh uji. Semua bahan akan menyerap air dengan cepat pada saat pencampuran dilakukan. Semen akan menggunakan air untuk melangsungkan proses hidrasi sedangkan air pada sekam padi tersimpan dalam rongga-rongga pori sekam padi. Air yang diserap oleh sekam padi dapat digunakan oleh semen untuk melakukan proses hidrasi sehingga jumlah air yang tersimpan pada rongga-rongga pori sekam padi menjadi berkurang ketika proses hidrasi selesai. Namun demikian karena porositas sekam padi yang cukup tinggi yaitu sekitar $79 \%$, maka jumlah air yang dapat tersimpan oleh sekam padi yaitu sekitar $790 \mathrm{~kg} / \mathrm{m}^{3}$. Dengan demikian sekam padi akan memiliki kemungkinan yang besar untuk menyimpan air dalam jumlah yang besar walaupun proses hidrasi telah selesai. Semakin banyak agregat sekam padi yang terdapat pada campuran semen maka semakin banyak air yang mungkin dapat tersimpan pada sekam padi setelah proses hidrasi selesai.

Nilai absorpsi contoh uji yang disebabkan oleh pengaruh faktor persentase sekam padi jika dinyatakan dalam persen adalah sebesar $30 \%$ pada B1 dan $35 \%$ pada B2. Jika dibandingkan dengan nilai absorpsi air komposit semen yang menggunakan jenis agregat lainnya maka nilai absorpsi air yang menggunakan sekam padi pada penelitian ini tergolong cukup besar. Cementbonded particleboard yang menggunakan partikel kayu Pinus silvestris pada komposisi $30 \%$ dari berat semen yang diteliti oleh Alpar et al. (2003) memiliki absorpsi air sebesar $24 \%$. Cementboard yang menggunakan serat sabuk kelapa pada komposisi $50 \%$ dari berat semen yang diteliti oleh Asasutjarit et al. (2007) memiliki absorpsi air sebesar $20 \%$. Sedangkan cementboard yang dibuat oleh Unifix Inc. yang menambahkan serat gelas pada lapisan permukaan memiliki absorpsi air di bawah $8 \%$ (Unifix Inc., 2009). Tetapi penelitian yang dilakukan oleh Subyakto dan Prasetya (1996) pada pulp 
cementboard yang dibuat dari agregat pulp bambu pada komposisi $30 \%$ dari berat semen menunjukkan nilai absorpsi air yang cukup besar yaitu $49,21 \%$. Hasil-hasil penelitian ini membuktikan bahwa kemampuan jenis serat untuk menyerap air berbeda sehingga nilai absorpsi air pada komposit semen yang dihasilkan juga berbeda.

Kemampuan air menembus rongga-rongga pori setelah contoh uji mengeras juga berpengaruh terhadap jumlah air yang dapat diserap oleh sekam padi. Contoh uji yang telah mengeras menghasilkan berbagai macam jenis rongga pori yang bisa berhubungan tergantung interkoneksitas yang terbentuk di antara pori satu dengan lainnya. Air harus melewati zona interfasial melalui interkoneksitas pori lainnya untuk mencapai permukaan sekam padi. Zona interfasial di permukaan sekam padi dapat berhubungan dengan pori gel dan pori kapiler tergantung pada banyaknya $\mathrm{CSH}$ dan $\mathrm{CH}$ yang terbentuk di sekeliling zona interfasial. Jika zona interfasial yang umumnya dikelilingi oleh kristal $\mathrm{CH}$ kemudian di antaranya terbentuk $\mathrm{CSH}$ primer yang membuat rongga pori kapiler atau pori gel yang ditutup oleh $\mathrm{CSH}$ sekunder maka air akan sulit memasuki wilayah zona interfasial. Demikian pula jika zona interfasial yang di sekitarnya terdapat banyak $\mathrm{CH}$ kemudian bereaksi dengan abu sekam padi maka akan terbentuk CSH sekunder yang akan menutup zona interfasial. Tetapi jika rongga-rongga pori ini tidak tertutup oleh pembentukan CSH sekunder maka rongga-rongga pori ini akan berhubungan dengan zona interfasial yang memudahkan air untuk diserap oleh sekam padi. $\mathrm{CH}$ yang banyak terdapat di sekitar zona interfasial ketika berhubungan dengan air akan memisahkan $\mathrm{Ca}^{2+}$ dan $\mathrm{OH}^{-}$larut pada larutan dalam pori yang mengakibatkan zona interfasial semakin terbuka sehingga air dan $\mathrm{Ca}^{2+}$ dapat diserap oleh sekam padi. Air akan mengisi pori-pori sekam padi sedangkan $\mathrm{Ca}^{2+}$ akan terikat pada asam silicic yang terbentuk dari silika sekam padi pada saat bereaksi dengan basa kuat semen. $\mathrm{Ca}^{2+}$ lainnya akan bergabung dengan silika abu sekam padi membentuk CSH sekunder yang akan memperkecil atau menutup ruang zona interfasial kembali. Sedangkan ion $\mathrm{OH}^{-}$hasil pemisahan $\mathrm{CH}$ akan mempertahankan kondisi basa larutan dalam pori untuk memutuskan ikatan silika pada abu sekam padi yang selanjutnya akan membentuk CSH sekunder.

Nilai absorpsi air contoh uji rata-rata sebagai akibat dari pengaruh faktor $C$ pada berbagai taraf perbandingan semen dan kapur dapat dilihat pada Histogram 3. Histogram 3 menunjukkan nilai absorpsi air contoh uji rata-rata karena pengaruh faktor $C$ (perbandingan semen dan kapur) masingmasing adalah $313,7,324,2$, dan $349,6 \mathrm{~kg} / \mathrm{m}^{3}$ yang terjadi pada perbandingan persentase semen dan kapur C1 (100:0), C2 (75: 25), dan C3 (50:50).

Hasil uji BNJ pada Tabel 3 mengenai pengaruh faktor $C$ (perbandingan persentase semen dan kapur) terhadap absorpsi air menunjukkan bahwa nilai absorpsi air contoh uji rata rata terendah sebesar $313,7 \mathrm{~kg} / \mathrm{m}^{3}$ terjadi pada perlakuan perbandingan persentase semen dan kapur $100: 0$ dan nilai absorpsi air contoh uji rata rata tertinggi sebesar $349,6 \mathrm{~kg} / \mathrm{m}^{3}$ terjadi pada perlakuan perbandingan persentase semen dan kapur $50: 50$. Tabel 3. menunjukkan pula bahwa perlakuan perbandingan persentase semen dan kapur $50: 50$ berbeda nyata dengan perlakuan perbandingan persentase semen dan kapur $75: 25$ dan $100: 0$. Demikian pula perlakuan perbandingan persentase semen dan kapur $75: 25$ berbeda nyata dengan perlakuan perbandingan persentase semen dan kapur $100: 0$.

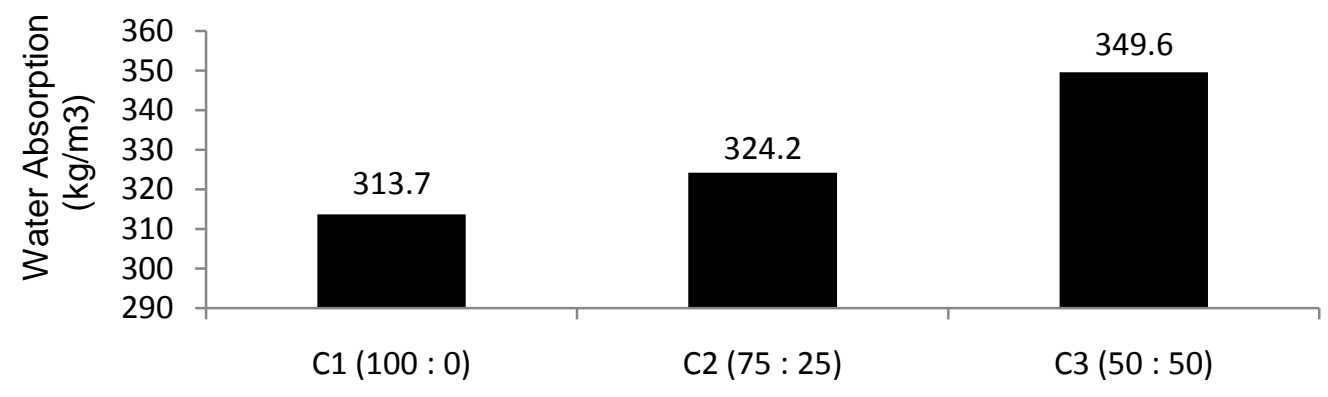

Cement and Lime Ratio (\%)

Figure 3. Main effect of cement and lime ratio to the water absorption 
Table 3. Tukey's HSD test of main effect $C$ (cement and lime ratio) to the water absorption $\left(\mathrm{kg} / \mathrm{m}^{3}\right)$

\begin{tabular}{|c|c|c|}
\hline $\mathrm{C}(\%)$ & $\begin{array}{c}\text { Average Water } \\
\text { Absorption } \\
\left(\mathrm{kg} / \mathrm{m}^{3}\right)\end{array}$ & BNJ 0,05 =7,96 \\
\hline $100: 0$ & 313,7 & $\mathrm{a}$ \\
$75: 25$ & 324,2 & $\mathrm{~b}$ \\
$50: 50$ & 349,6 & $\mathrm{C}$ \\
\hline Remark: same letter indicate no significant \\
difference
\end{tabular}

Perbedaan nilai absorpsi air contoh uji akibat perlakuan faktor perbandingan persentase semen dan kapur pada Tabel 3 disebabkan oleh karena bertambahnya persentase kapur pada perbandingan persentase semen dan kapur. Semakin banyak kapur pada pasta campuran semen maka jumlah $\mathrm{CH}$ yang terbentuk akan semakin banyak dan sebaliknya jumlah $\mathrm{CSH}$ yang terbentuk semakin sedikit.

Air pada campuran digunakan untuk menghasilkan $\mathrm{CSH}, \mathrm{CH}$ dan senyawa hasil hidrasi lain. Pada saat setelah setting dan harden selesai, sisa air yang tidak bereaksi dalam contoh uji berada pada pori gel, pori kapiler, zona interfasial, dan terikat pada $\mathrm{CSH}$. Air yang berada pada ronggarongga pori dapat melakukan transportasi sedangkan yang terikat pada CSH tidak dapat berpindah kecuali pada suhu di atas $1000^{\circ} \mathrm{C}$. Dalam keadaan jenuh pada saat air masuk ke dalam contoh uji maka air akan mengisi rongga-rongga pori dan dapat melakukan transportasi ke seluruh bagian berongga yang saling terhubung dalam contoh uji. Gerakan air tergantung struktur pori (koneksitas antar rongga pori dan ukuran pori), kondisi contoh uji (retak), mekanisme ikatan (jenis unsur yang terikat oleh air), kondisi lingkungan (suhu, kelembaban dan tekanan), dan mekanisme transportasi (absorpsi kapiler, penetrasi karena tekanan, dan difusi). Kecepatan air masuk ke dalam contoh uji sangat tergantung pada gaya kapilaritas pada pori kapiler. Gaya kapilaritas tergantung tegangan permukaan, viskositas, dan kerapatan cairan. Gerakan air kapiler lebih cepat terjadi pada pori yang memiliki ukuran yang lebih kecil.

Jumlah $\mathrm{CSH}$ yang sedikit walaupun menghasilkan jumlah rongga pori kapiler yang sedikit tetapi cenderung membentuk rongga pori berukuran besar karena kurangnya kumpulan $\mathrm{CSH}$ yang terbentuk. Selain itu CSH memiliki sifat yang kurang kristalin sehingga dapat membentuk rongga kecil (micro void) di wilayah amorf. Jika struktur CSH tidak tersusun oleh banyak CSH maka rongga kecil ini akan terbuka untuk menyerap air. Jumlah kapur yang banyak akan menghasilkan $\mathrm{CH}$ yang banyak dan bersifat kristalin serta tidak berongga. tetapi dapat larut dalam air yang menyebabkan $\mathrm{CH}$ terurai sehingga dapat memperbesar pori terutama pada zona interfasial. Zona interfasial akan membesar dan dapat menghubungkan dengan pori kapiler sehingga air akan dapat masuk ke permukaan sekam padi. Karena ukuran pori menjadi besar maka jumlah air yang diserap juga menjadi lebih banyak.

\section{KESIMPULAN}

Penambahan pozzolan abu sekam padi sebesar $20 \%, 30 \%$, dan $40 \%$ menurunkan nilai absorpsi air komposit semen sekam padi namun hanya abu sekam padi sebesar $20 \%$ dan $30 \%$ yang memenuhi syarat ASTM C 90. Sedangkan penambahan kapur meningkatkan nilai absorpsi air komposit semen sekam padi.

\section{DAFTAR PUSTAKA}

Alpar, T., Takats, P., and Hatano, Y. 2003. Porosity of Cement-Bonded Particleboards Hardened by $\mathrm{CO} 2$ Injection and Cured by Hydration. JARQ. 37 (4): 263 - 268.

Asasutjarit, C., Hirunlabh, J., Khedari, J., Charoenvai, S., Zeghmati, B., and Shin, U. C. 2007. Development of Coconut Coir-based Lightweight Cement board. Construction and Building Materials. 21: 277-288.

Bentz, D. P. 2007. Cement hydration: building bridges and dams at the microstructure level. Materials and Structures. 40: 397- 404.

Dakroury, A. El. and Gasser, M. S. 2008. Rice Husk Ash (RHA) as Cement Admixture for Immobilization of Liquid Radioactive Waste at Different Temperatures. Journal of Nuclear Materials. 381: 271- 277.

DTI. 2003. Rice Husk Ash Market Study. DTI/Pub URN 03/668. United Kingdom: Brozeoak Ltd (Contractor).

Ganesan, K., Rajagopal, K., and Thangavel, K. 2008. Rice husk ash blended cement: Assessment of Optimal Level of Replacement for Strength and Permeability Properties of 
Concrete. Construction and Building Materials. 22 (8): 1675 - 1683.

Harsono, H. 2002. Pembuatan Silika Amorf dari Limbah Sekam Padi. Jurnal ILMU DASAR. 3 (2): 98 -103.

$\mathrm{Hu}$, J. and Stroeven, P. 2005. Size Characterisation of Pore Structure for Estimating Transport Properties of Cement Paste. Heron. 50 (1): $41-54$.

Ismail, M. S. and Waliuddin, A. M. 1996. Effect of Rice Husk Ash on High Strength Concrete. Construction and Building Materials. 10 (1): $521-526$

Jauberthie, R., Rendell, F. Tamba, S. and Cisse', I. K. 2000. Origin of the Pozzolanic Effect of Rice Husks. Construction and Building Materials. 14: 419 - 423.

Kaboosi, K. 2007. The Feasibility of Rice Husk Application as an Envelope Material in Subsurface Drainage System. Islamic Azad University, Science and Research Branch. Tehran, Iran.

Muthadhi, A., Anitha, R. and Kothandaraman, S. 2007. Rice Husk Ash - Properties and Its Uses: A Review. IE(I) Journal-CV, 88: 50 56.

Peterson, V. K., Neumann, D. A, and Livingston, R. A. 2006. Hydration of Cement: The
Application of Quasielastic and Inelastic Neutron Scattering. Physica. B: 481- 486.

Saraswathy, V. and Song, Ha-Won. 2007. Corrosion Performance of Rice Husk Ash Blended Concrete. Construction and Building Materials. 21: 1779-1784.

Shihonara, Y. and Kohyama, N. 2004. Quantitative Analysis of Tridymite and Cristobalite Crystallized in Rice Husk Ash by Heating. Industrial Health. 42: 277- 285.

Singh, N. B., Singh, V. D., Rai, S. and Chaturvedi, S. 2002. Effect of lignosulfonate, calcium chloride and their mixture on the hydration of RHA-blended Portland cement. Cement and Concrete Research. 32: 387-392.

Subyakto dan Prasetya, B. 1996. Sifat Fisik dan Mekanik Papan Pulp Semen (Pulp Cementboard) dari Bahan Lignoselulosa. Prosiding Seminar Fisika. Jakarta. 40 - 47.

Thomas, J. J., Allen, A. J., and Jennings, H. M. 2008. Structural Changes to the CalciumSilicate-Hydrate Gel Phase of Hydrated Cement with Age, Drying, and Resaturation. J. Am. Ceram. Soc. 10: 1 -8.

UNIFIX Inc. 2000. PermaBase Cement Board Construction Guide. UNIFIX Inc. Bromont, Canada.

Diterima : 12 Desember 2009

\section{Bakri dan Bahruddin}

Lab. Pemanfaatan dan Pengolahan Hasil Hutan

Department of Forestry, Forestry Faculty

Hasanuddin University - Indonesia 
Appendix 1. The observation of water absorption $(\mathrm{kg} / \mathrm{m} 3)$ to the test sample

\begin{tabular}{|c|c|c|c|c|c|c|c|}
\hline \multirow{2}{*}{\multicolumn{3}{|c|}{ Perlakuan }} & \multicolumn{3}{|c|}{ Ulangan } & \multirow{2}{*}{ Total } & \multirow{2}{*}{ Rata-rata } \\
\hline & & & 1 & 2 & 3 & & \\
\hline \multirow[t]{6}{*}{$\mathrm{A} 0$} & B1 & C1 & 325.6 & 339.8 & 320.2 & 985,6 & 328,5 \\
\hline & & C2 & 331.7 & 345.3 & 328.5 & 1005,5 & 335,2 \\
\hline & & C3 & 350.9 & 362.0 & 350.2 & 1063,1 & 354,4 \\
\hline & B2 & $\mathrm{C} 1$ & 339.7 & 360.6 & 329.9 & 1030,2 & 343,4 \\
\hline & & $\mathrm{C} 2$ & 364.4 & 372.6 & 363.9 & 1100,9 & 367,0 \\
\hline & & C3 & 370.8 & 384.4 & 369.4 & 1124,6 & 374,9 \\
\hline \multirow[t]{6}{*}{$\mathrm{A} 1$} & B1 & C1 & 270.0 & 289.6 & 265.6 & 825,2 & 275,1 \\
\hline & & C2 & 284.9 & 303.4 & 140.7 & 865,0 & 288,3 \\
\hline & & C3 & 328.3 & 348.2 & 320.4 & 996,9 & 332,3 \\
\hline & B2 & $\mathrm{C} 1$ & 301.3 & 327.8 & 296.6 & 925,7 & 308,6 \\
\hline & & C2 & 314.3 & 334.2 & 308.7 & 957,2 & 319,1 \\
\hline & & C3 & 330.1 & 360.6 & 321.0 & 1011,7 & 337,2 \\
\hline \multirow[t]{6}{*}{$\mathrm{A} 2$} & B1 & C1 & 270.0 & 293.1 & 269.7 & 832,8 & 277,6 \\
\hline & & $\mathrm{C} 2$ & 289.5 & 309.8 & 279.8 & 879,1 & 293,0 \\
\hline & & $\mathrm{C} 3$ & 334.1 & 348.3 & 330.1 & 1012,5 & 337,5 \\
\hline & B2 & $\mathrm{C} 1$ & 331.2 & 322.7 & 322.1 & 976,0 & 325,3 \\
\hline & & C2 & 325.1 & 335.4 & 316.9 & 977,4 & 325,8 \\
\hline & & $\mathrm{C} 3$ & 349.6 & 368.0 & 339.9 & 1057,5 & 352,5 \\
\hline \multirow[t]{6}{*}{ A3 } & B1 & C1 & 312.3 & 320.7 & 310.2 & 943,2 & 314,4 \\
\hline & & $\mathrm{C} 2$ & 320.8 & 330.5 & 319.9 & 971,2 & 323,7 \\
\hline & & $\mathrm{C} 3$ & 341.7 & 350.8 & 338.2 & 1030,7 & 343,6 \\
\hline & B2 & $\mathrm{C} 1$ & 336.5 & 344.5 & 330.1 & 1011,1 & 337,0 \\
\hline & & C2 & 339.7 & 350.7 & 334.4 & 1024,8 & 341,6 \\
\hline & & $\mathrm{C} 3$ & 361.8 & 372.1 & 357.5 & 1091,4 & 363,8 \\
\hline
\end{tabular}

